\title{
DEMAND ON SECTIO CAESAREA'S LABOR AMONG PREGNANT WOMEN IN DEVELOPING COUNTRIES: A SCOPING REVIEW
}

\author{
Maisaroh Nurasih, Cesa Septiana Pratiwi
}

Universitas ‘Aisyiyah Yogyakarta

\begin{abstract}
Background: The Sectio Caesarea (SC) has continued to increase in the last decades, both globally and in developing countries. SC is not only performed on medical indications but is also performed at the request of the mother so that it has an impact on increasing CS in general. This study aimed to review the demand on Sectio Caesarea's labor among pregnant women in developing countries.

Subjects and Method: This scoping review method was selected for this study using the Arksey and O'Malley framework. This study consisted of 5 stages, namely: 1) Identifying the scoping review questions with the Population Intervention Comparison Outcome (PICO) Framework; 2) Identifying articles relevant to inclusion and exclusion criteria, conducting literature searches through PubMed, Sciencedirect, Wiley and EBSCO, searching for gray literature through search engines, namely google scholar; 3) Article selection using Covidance Software with PRISMA Flowchart (Preferred Reporting Items for Systematic reviews and MetaAnalyzes) to describe the flow search literature, conduct critical appraisal using The Joanna Briggs Institute (JBI) Critical Appraisal Tools to assess the quality of articles; 4) Mapping data (data charting);and 5) Compile, summarize and report results.

Results: Based on 5 articles that fit the inclusion criteria, the study design used included were qualitative, cross sectional, mix methods. Articles obtained were came from developing countries, 2 Iranian, 1 Jordan, 1 Nigerian, and 1 Cambodia. Two themes emerge from this study, namely the factors affecting the demand for SC and the role of antenatal education.

Conclusion: The formation of positive and trusting relationships between women, families and health care providers can result in proper communication. Meaningful discussion is important for women in making labor decisions.
\end{abstract}

Keywords: sectio caesarea, demand for pregnant women, developing countries

Correspondence:

Maisaroh Nurasih. Universitas 'Aisyiyah Yogyakarta. Jl. Ringroad Barat No. 63, Mlangi

Nogotirto, Gamping, Rice Field Area, Nogotirto, Gamping District, Sleman Regency, Yogyakarta. Email: maisarohubay24@gmail.com: Mobile: +6282137175569

The $7^{\text {th }}$ International Conference on Public Health

Solo, Indonesia, November 18-19, 2020 | 196 https://doi.org/10.26911/the7thicph.03.16 